FOKUS

Jurnal Kajian Keislaman

dan Kemasyarakatan
Institut Agama Islam Negeri (IAIN) Curup, Indonesia

ISSN 2548-334X (p); 2548-3358 (e)

volume 6, number 2, 2021 | page: 105-130

DOI: http://doi.org/10.29240/jf.v6i2.3391

\title{
Pengembangan Sikap Keberagamaan Remaja melalui Pendidikan Sufistik
}

\author{
Ossi Marga Ramadhan1, Opik Taufik Kurahman², Supiana³, Hisny \\ Fajrussalam $^{4}$ \\ 1,2,3Universitas Islam Negeri Sunan Gunung Djati, ${ }^{4}$ Universitas Pendidikan Indonesia \\ 10ssiramadhan33@gmail.com, ${ }^{2}$ opik@uinsgd.ac.id, ${ }^{3}$ supiana@uinsgd.ac.id, \\ 4hfajrussalam@upi.edu
}

\begin{abstract}
This study aims to determine the offer and integration of Sufistic education on adolescent religious attitudes. This research uses a descriptive qualitative approach with the type of library research. Researchers obtain data from various literature such as books, journals, scientific works, and other documents that examine research-related themes. The data obtained is then analyzed by first reducing the data, presenting the data, and drawing conclusions. The results found that Sufistic education can be reviewed and integrated into aspects of adolescent attitude formation (cognitive, affective, conative) by studying Shari'a education with the aim of Sufism in the cognitive aspect, through a psychological-humanist approach in the affective aspect, and through tafakkur activities to perfect the conative aspect. The creation of these three aspects must be supported by religious disciplines in their environments, such as character and role models from teachers and parents, instilling a sense of faith in adolescents, and a good religious environment.
\end{abstract}

Keywords: Sufistic Education; Religious Attitudes; Adolescent; Religious Development

Abstrak. Penelitian ini memiliki tujuan untuk mengetahui tawaran dan
integrasi pendidikan sufistik terhadap sikap keberagamaan remaja. Penelitian
ini menggunakan pendekatan kualitatif deskriptif berjenis penelitian
kepustakaan. Peneliti memperoleh data dari berbagai literatur seperti buku,
jurnal, karya ilmiah, dan dokumen lain yang mengkaji mengenai tema terkait
penelitian. Data yang diperoleh kemudian dianalisis dengan terlebih dahulu
mereduksi data, kemudian menyajikan data, dan menarik kesimpulan. Hasilnya
menemukan bahwa pendidikan sufistik dapat ditinjau dan diintegrasikan ke
dalam aspek pembentukan sikap remaja (kognitif, afektif, konatif), yakni dengan
mempelajari pendidikan syariat dengan tujuan tasawuf dalam aspek kognitif,
melalui pendekatan psikologis-humanis dalam aspek afektif, dan melalui
aktifitas tafakkur untuk menyempurnakan aspek konatif. Terciptanya ketiga
aspek tersebut harus didukung oleh kedisiplinan beragama di lingkungannya, 
seperti pekerti dan keteladanan dari sosok guru serta orang tua, menanamkan rasa keimanan pada remaja, dan tatanan lingkungan keagamaan yang baik.

Kata Kunci: Pendidikan Sufistik; Sikap Keagamaan; RemajaPerkembangan Keberagamaan

\section{Pendahuluan}

Kondisi dewasa ini yang ditandai dengan kemajuan dalam aspek teknologi informasi dan komunikasi memiliki dampak kemudahan fasilitatif dalam berbagai sendi-sendi kehidupan masyarakat. Akan tetapi pada gilirannya, kondisi ini berdampak pula pada perubahan tatanan budaya dan pola perilaku manusia. Mulkhan menyebutkan kondisi seperti ini mendorong timbulnya pandangan baru dalam hal nilai-nilai sosial, spiritual, maupun keagamaan ${ }^{1}$. Menurut Bafadal, era globalisasi ini memiliki dampak terhadap krisis remaja, seperti (1) meleburnya norma sosial, (2) bertumbuhnya fenomena kenakalan hingga kriminalitas, dan (3) lunturnya semangat nasionalisme².

Peleburan nilai-nilai sosial ini menurut Mareta diindikasikan dengan memudarnya pedoman normatif, seperti asas hukum positif, hukum keagamaan, atupun kultur etika yang selama ini dianut masyarakat secara umum ${ }^{3}$. Hal ini mengakibatkan para remaja cenderung tak memperdulikan lagi lingkungan sekitar, perintah agama, bahkan tak sedikit remaja yang terlilit pada kasus kriminal. Komisi Perlindungan Anak Indonesia (KPAI) dalam Sulastri menyebutkan angka tindakan tawuran antar pelajar dalam setiap tahunnya mengalami peningkatan, hingga tahun 2018 angka tindak kriminal tawuran remaja meningkat sebesar $14 \%{ }^{4}$.

Problematika fenomena social normlessness pada usia remaja pun ditandai dengan beberapa kasus penyalahgunaan narkoba seperti sabu-sabu, mariyuana, obat-obat terlarang dan sebagainya. Merujuk pada data yang diliris

1 Abdul Munir Mulkhan, Nalar Spiritual Pendidikan: Solusi Problem Filosofis Pendidikan Islam (Yogyakarta: Tiara Wacana Yogya, 2002), 49.

${ }^{2}$ Fadhal AR Bafadal, Pemuda dan Pergumulan Nilai pada Era Global (Jakarta: Badan Litbang Agama dan Diklat Keagamaan, 2003), 53.

3 Mira Mareta, "Peran Pendidikan Agama dalam Pembentukan Perilaku Keberagamaan Siswa Madrasah Aliyah Pedesaan dan Perkotaan di Pulau Lombok", Doktoral, Disertasi, UIN Sunan Kalijaga, 2019, 1.

${ }^{4}$ Sulastri Lastri, Eti Hayati, dan Aulia Nursyifa, "Dampak Kenakalan Remaja Untuk Meningkatkan Kesadaran Dari Bahaya Kenakalan Remaja Bagi Masa Depan," Jurnal Loyalitas Sosial: Journal of Community Service in Humanities and Social Sciences 2, no. 1 2020, (DOI: 10.32493/jls.v2i1.y2020), 16. 
oleh Badan Narkotika Nasional (BNN) hingga tahun 2017 mencatat bahwa sebanyak 3.376.115 orang di Indonesia adalah pengguna narkoba5. Kemudian pada 2019 penyalahgunaan narkoba di kalangan remaja meningkat menjadi 24$28 \%$ yang sebelumnya hanya $20 \%{ }^{6}$. Tak cukup dengan tingginya angka kasus narkoba di kalangan remaja saja, Kemenkes RI mencatat persentase pengidap AIDS dari tahun 2005-2019 di dominasi oleh kelompok remaja, yakni sebesar $63,1 \%$, artinya bahwa 6 dari 10 penderita AIDS di Indonesia adalah kelompok remaja 7 .

Catatan hitam akibat dari beberapa tindakan amoral remaja di atas merupakan sebab dari berbagai permasalahan yang sangat kompleks. Meliputi berbagai faktor, seperti ranah sosiologis, kebudayaan, serta psikologis, atau bahkan faktor strategi pendidikan ${ }^{8}$. Dalam hal psikologis, masa ini memang dihiasi dengan berbagai gejolak serta gelombang pada dirinya, akibat dari suasana kejiwaan yang memang fluktuatif, sehingga mereka sering merasa frustasi, terjadi konflik, hadirnya krisis dan sebagainya. Sementara itu, kemampuan remaja dalam mengatasi berbagai gejolak dan gelombang ini akan berdampak pada fase kehidupan selanjutnya ${ }^{9}$.

Masa remaja ditandai juga dengan metamorfosis dalam hal fisik, pun dengan perubahan dalam hal sikap dan perilaku yang labil. Menurut Hurlock secara umum masa remaja mengalami beberapa perubahan seperti (1) emosi yang memuncak, (2) dan (3) perubahan fisik, atensi dan sosok yang diinginkan oleh lingkungan sosial, (4) pealihan nilai-nilai dan (5) bersikap ambivalen terhadap setiap perubahan ${ }^{10}$. Dari deskripsi tersebut menggambarkan bahwa masa remaja mengalami perkembangan identitas diri dan membutuhkan support system pada kehidupannya.

\footnotetext{
5 Deti Mega Purnamasari, "Kementerian PPPA: Naiknya Kasus Narkoba Anak Jadi Alarm bagi Orangtua," kompas.com, diakses 13 Februari 2021, https://nasional.kompas.com/read/2020/06/26/17590051/kementerian-pppanaiknya-kasus-narkoba-anak-jadi-alarm-bagi-orangtua?page=all.

${ }^{6}$ Puslitdatin, "Penggunaan Narkotika di kalangan Remaja Meningkat," bnn.go.id, diakses 13 Februari 2021, https://bnn.go.id/penggunaan-narkotika-kalangan-remajameningkat/.

${ }^{7}$ Gaby Gabriela Langi, “Millenials dan HIV Aids,” pph.atmajaya.ac.id, diakses 13 Februari 2021, https://pph.atmajaya.ac.id/berita/artikel/millennials-dan-hiv-aids/.

8 Mareta, "Peran Pendidikan Agama dalam Pembentukan Perilaku Keberagamaan Siswa Madrasah Aliyah Pedesaan dan Perkotaan di Pulau Lombok," 2.

${ }_{9}^{9}$ Ahmad Tafsir et al., Cakrawala Pemikiran Pendidikan Islam, vol. 1 (Bandung: Mimbar Pustaka: Media Tranformasi Pengetahuan, 2004), 58.

10 Ibid., 1:59.
} 
Keinginan dan kebutuhan manusia pada dasarnya tidak cukup dengan pemenuhan kebutuhan primernya saja, lebih dari itu dalam perkembangannya, manusia membutuhkan hal yang bersifat kodrati, berupa kebutuhan batin untuk dicintai dan mencintai dzat yang maha perkasa ${ }^{11}$. Dalam ilmu sosial, hal tersebut dikenal dengan istilah homo-religius, makhluk yang berada pada alam sakral dan menikmati sakralitas yang ada pada diri sendiri dan sekitarnya ${ }^{12}$.

Kekuatan substansial yang mengaktualisasikan diri secara hakiki namun konkret dalam mengenal pusat eksistensi ini yang menurut sufi besar Syaikh Ibnu 'Arabi harus dikembangkan melalui potensi 'al-Khayal', yang digerakkan menuju penyingkapan diri dalam dunia indrawi yang bersifat abadi dan 'azali ${ }^{13}$. Agar kehidupan diasingkan dari pola yang hanya berputar di pusaran eksistensinya saja. Hal tersebut seyogyanya di awali dengan rasa yang dalam pada kebutuhannya terhadap agama, yang kemudian termanifestasikan pada perilaku beragama.

Pembentukan perilaku di dalam beragama memiliki kaitan yang erat dengan sikap dalam keberagamaan. Melalui sikap keagamaan yang paripurna akan membuahkan perilaku beragama yang juga baik. Pun sebaliknya, apabila sikap dalam keberagamaannya tidak baik maka akan menghadirkan perilaku yang juga kurang baik. Oleh karenanya dalam membentuk perilaku remaja dalam hal keberagamaannya, hendaknya harus diawali dari membentuk sikap keberagamaannya ${ }^{14}$.

Sikap remaja yang khas dengan kelabilannya menggambarkan bahwa di dalam dirinya kerap terjadi gejolak, akibatnya kepribadiannya bersifat fluktuatif, pendiriannya dapat berubah seketika, oleh karena itu mereka beranggapan untuk mencari alternatif lain yang mereka anggap sebagai hiburannya ${ }^{15}$. Alternatif ini seyogyanya diarahkan pada hal yang bersifat kebajikan, jika sebaliknya maka akan berakhir seperti pada fenomena penyimpangan perilaku dan perbuatan amoral yang dilakukan remaja. Di sisi

${ }^{11}$ Ahmad Zakki Mubarak, "Perkembangan Jiwa Agama," Ittihad Jurnal Kopertais Wilayah XI 12, no. 22 (2017): 91.

12 Dadang Kahmad, Sosiologi Agama (Bandung: Remaja Rosdakarya, 2000), 119. 2006), 54 .

13 Said Aqil Siradj, Tasawuf sebagai Kritik Sosial (Bandung: Mizan Pustaka,

${ }^{14}$ Sutarto Sutarto, "Pengembangan Sikap Keberagamaan Peserta Didik," Islamic Counseling: Jurnal Bimbingan dan Konseling Islam 2, no. 1, 2018, (DOI: 10.29240/jbk.v2i1.468), 22.

${ }^{15}$ Eddy Saputra, "Dampak Sosial Media Terhadap Sikap Keberagamaan Remaja Dan Solusinya Melalui Pendidikan Agama Islam," Sosio e-Kons 8, no. 2, 2016, (DOI: 10.30998/sosioekons.v8i2.922), 161. 
lain, penyimpangan tersebut berawal dari krisis identitas agama yang dimilikinya, akibatnya remaja mudah terperangkap dengan lingkungan yang kurang baik.

Kehampaan identitas agama yang berpusat dari aspek rohaniyah dalam diri remaja ini mudah terpedaya dalam timbulnya berbagai permasalahan, baik yang bersifat pribadi maupun sosial. Dalam hal personal, secara empiris manusia pada hakikatnya ingin hidup secara damai dan utuh ${ }^{16}$. Sedangkan dalam karakteristiknya, al-Taftazani memaparkan pendekatan sufistik secara psikis dapat memberikan ketenteraman dan kebahagiaan, sebab bertindak sebagai pengontrol dari beragamnya hasrat hawa nafsu dan pemantik keharmonian psikis bagi manusia ${ }^{17}$. Begitupun dengan Anwar dan Solikhin yang menyatakan ilmu tasawuf menerangkan mengenai cara praktis dalam merasakan keyakinan serta ketentraman hati, termasuk caranya dalam melindungi diri dari kemunafikan ${ }^{18}$.

Sejauh penelusuran yang ditemukan, telah banyak peneliti sebelumnya yang mengkaji mengenai tema yang terkait. Seperti sosial media yang memiliki dampak pada sikap keberagamaan remaja yang secara bersamaan pembelajaran pendidikan agama Islam memiliki peran dalam membentenginya ${ }^{19}$, dalam lingkungan sekolah, pendidikan sufistik dapat diterapkan dengan latihan-latihan jiwa ${ }^{20}$, pun dapat diterapkan dan dikembangkan pada lingkungan keluarga melalui cara-cara yang strategis ${ }^{21}$, yang mana menurut Ibnu Qayyim harus diterapkan sejak dini, sebab berimplikasi pada kebahagiaannya di masa dewasa ${ }^{22}$, selain itu dalam segi

16 Fitriana Fitriana dan Feriska Listrianti, "Pendidikan Akhlak Perspektif AlGhazali dalam Mengatasi Rational Hedonism di MTS Negeri 1 Probolinggo," Risâlah, Jurnal Pendidikan dan Studi Islam 6, no. 1, March (2020): 101.

${ }_{17} \mathrm{Abu}$ al-Wafa al-Ghanimi Al-Taftazani, Sufi dari Zaman ke Zaman (Bandung: Pustidaka, 1985), 4-5. 2004), 96-97.

${ }^{18}$ Rosihon Anwar dan Mukhtar Solikhin, Ilmu Tasawuf (Bandung: Pustaka Setia,

${ }^{19}$ Saputra, "Dampak Sosial Media Terhadap Sikap Keberagamaan Remaja Dan Solusinya Melalui Pendidikan Agama Islam," 167.

${ }^{20}$ A. Qomarudin, "Pendekatan Sufistik dalam Pembelajaran Pendidikan Agama Islam," Piwulang: Jurnal Pendidikan Agama Islam 2, no. 1, 2019, (DOI: 10.32478/piwulang.v2i1.299), 25.

${ }^{21}$ Safrudin Aziz, "Pendidikan Spiritual berbasis Sufistik bagi Anak Usia Dini dalam Keluarga," Dialogia: Jurnal Studi Islam Dan Sosial 15, no. 1, 2017, (DOI: 10.21154/dialogia.v15i1.1188) 132.

22 Anggi Anggraeni Islami dan Rifki Rosyad, "Pendidikan Anak Perspektif Sufistik Dalam Pandangan Ibnu Qayyim Al Jauziyah," Syifa al-Qulub 4, no. 2, 2020, (DOI: 10.15575/saq.v4i2.7587), 46. 
sosial, pendidikan sufistik berkontribusi dalam mewujudkan perdamaian dan berefektif dalam mengurangi konflik ${ }^{23}$.

Berdasarkan uraian di atas, peneliti bermaksud untuk mengisi kekosongan kajian yang lebih terfokus mengenai pengembangan sikap keberagamaan pada usia remaja melalui upaya pendidikan sufistik. Hal ini pun juga yang membuat peneliti tertarik dalam melakukan kajian, sebab remaja dengan segala ciri khas-nya memiliki problematika yang demikian kompleks.

Adapun metode yang dipakai pada penelitian ini ialah dengan analisis deskriptif melalui pendekatan kualitatif yang berjenis penelitian kepustakaan, peneliti mengambil data dari beragam sumber dan referensi seperti jurnal penelitian, buku, serta sumber lain yang relevan. Setelah data terkumpul, peneliti melakukan reduksi data terlebih dahulu agar data lebih terfokus pada tema penelitian, setelah itu data disajikan, dan dilakukan penarikan kesimpulan. Metode tersebut digunakan dengan bertujuan untuk memberikan gambaran tentang pendidikan sufistik, sikap keberagamaan remaja dan upaya pengembangan sikap keberagamaan remaja melalui pendidikan sufistik.

\section{Hasil dan Pembahasan}

\section{Sikap Keberagamaan Remaja}

Manusia dalam melaksanakan proses kehidupannya akan selalu berinteraksi dengan sesamanya, proses interaksi terhadap situasi yang ada dan terwujud dengan kesadaran untuk menentukan perbuatan inilah yang disebut dengan sikap. Beberapa peneliti menyebutkan bahwa sikap bukan hanya berkaitan dengan kesadaran dalam perbuatan yang telah terjadi saja, akan tetapi kesadaran dalam perbuatan yang mungkin akan terjadi ${ }^{24}$. Dengan kata lain, sikap dapat menentukan sifat dan makna dari tindakan yang akan atau sedang dilakukan ${ }^{25}$.

Sikap satu orang dengan yang lainnya dalam merespon suatu rangsangan dapat menghasilkan output yang berbeda. Purwanto memaparkan bahwa perasaan dan respon memiliki porsi yang akan menentukan dalam

23 A Gani, "Pendekatan Sufistik Dalam Pendidikan Islam Berwawasan Perdamaian," AKADEMIKA: Jurnal Pemikiran Islam 23, no. 2, 2018, (DOI: 10.32332/akademika.v23i2.1239, 388.

24 Saifuddin Azwar, Sikap Manusia Teori dan Pengukurannya, Edisi ke-2 (Yogyakarta: Pustaka Pelajar, 2013), 29.

${ }^{25}$ Sutarto, "Pengembangan Sikap Keberagamaan Peserta Didik," 24. 
bersikap ${ }^{26}$. Sutarto menjelaskan lebih rinci bahwa perbedaan seseorang dalam merespon stimulus ditentukan oleh beberapa hal, seperti adanya perbedaan dalam hal atensi, pengetahuan, semangat perasaan, kondisi lingkungan, pengalaman, termasuk di dalamnya perbedaan seseorang di dalam sikap keberagamaannya ${ }^{27}$.

Keberagamaan menurut Jalaluddin Rakhmat merupakan kecenderungan seseorang dalam bertindak di kehidupannya agar sesuai dengan perintah agamanya ${ }^{28}$. Sedangkan Sahlan menyebutkan keberagamaan ditentukan oleh sikap manusia dalam menjalankan syariat yang didasari oleh keyakinannya ${ }^{29}$. Hal tersebut senada dengan pernyataan Tafsir yang menegaskan bahwa keberagamaan memiliki core, yakni sikap beragama. Sedangkan sikap beragama dalam sudut pandang Islam adalah iman ${ }^{30}$. Darinya dapat dipahami bahwa sikap keagamaan merupakan perbuatan yang dilakukan secara sadar yang dilandasi dengan dasar keimanan sebagai wujud dari pelaksanaan ajaran agamanya.

Sikap keberagamaan dalam setiap fase-nya sangat berbeda, dan hal ini seyogyanya harus dipahami oleh setiap orang tua, bahwa hal tersebut bergantung pada tingkat perkembangannya, agar tidak terjadi kesalahpahaman dalam memperlakukan anaknya, yang mungkin dapat membuat mereka mencari lingkungan yang salah dan berakhir pada tindakan amoral. Pada fase anak-anak, sikap keberagamaan cenderung berpola ideas concept on authority, yakni dalam konsep keberagamaannya anak-anak cenderung dipengaruhi oleh unsur dari luar dirinya ${ }^{31}$. Pun berbeda dengan sikap keberagamaan orang dewasa, yang sudah bersifat realistis, kritis dan sudah bertaraf pada pendalaman makna, serta ketaatannya dalam beragama adalah buah dari pertimbangan yang matang dan penuh dengan rasa tanggungjawab ${ }^{32}$.

Berbeda pula dengan remaja yang tengah mengalami masa pergeseran dari fase kanak-kanak menuju kedewasaan yang memiliki sikap keberagamaan

26 Ngalim Purwanto, Psikologi Pendidikan (Bandung: Remaja Rosdakarya, 2004), 141.

27 Sutarto, "Pengembangan Sikap Keberagamaan Peserta Didik," 26.

28 Jalaluddin Rakhmat, Psikologi Agama: Sebuah Pengantar (Bandung: Mizan Pustaka, 2013), 116.

29 Asmaun Sahlan, Mewujudkan Budaya Religius di Sekolah: Upaya Mengembangkan PAI dari Teori ke Aksi (Malang: UIN Maliki-Press, 2010), 66.

30 Ahmad Tafsir, Metodologi Pengajaran Agama Islam (Bandung: Remaja Rosdakarya, 2008), 85.

${ }^{31}$ Ramayulis, Psikologi Agama (Jakarta: Kalam Mulia, 2019), 56.

32 Ibid., 78-79. 
secara khusus. Sikap ini ditandai dengan beberapa karakteristik yang dimilikinya, seperti (1) mengikuti lingkungan, remaja memiliki kecenderungan dalam mengikuti suasana yang terjadi di lingkungannya, apabila lingkungannya percaya dan gemar melaksanakan perintah agama, maka remaja akan cenderung mengikutinya tanpa mendalami makna yang lebih dalam. (2) percaya dengan kesadaran, pada masa transisi ini, sikap keberagamaan remaja sudah mulai pada taraf penemuan pengalaman dan penghayatan terhadap ajaran agamanya.

Karakteristik sikap keberagamaan remaja yang selanjutnya adalah (3) kebimbangan, hal ini dapat muncul karena proses alamiah yang dirasakan oleh remaja, seperti guncangan yang berpangkal dari reaksi perubahan di dalam dirinya, atau kebimbangan yang berasal dari kesenjangan antara yang dimilikinya dengan kenyataan yang ada disekitarnya. (4) tidak percaya sama sekali, emosi remaja yang cenderung belum stabil memungkinkan remaja untuk cenderung tidak percaya pada agamanya, hal ini merupakan bentuk 'protes' terhadap kenyataan yang tidak sesuai dengan ekspektasinya, seperti timbulnya rasa sakit hati atau kecewa yang berlapis-lapis, hingga kemudian ia merasa paling menderita, sehingga remaja berputus asa kepada keadilan dan kekuasaan Allah ${ }^{33}$.

Sikap keberagamaan bukanlah sesuatu yang bersifat genetik, namun dalam perkembangannya dapat dibentuk dan dibina. Zakiah Daradjat mengungkapkan bahwa sikap keberagamaan dapat dibentuk melalui pengalaman secara langsung, seiring interaksinya terhadap berbagai unsur di dalam lingkungan sosial-nya ${ }^{34}$. Pendapat ini dikuatkan oleh Gerungan yang menyatakan bahwa sikap bukan merupakan hal yang bersifat bawaan, akan tetapi pada gilirannya dapat dibentuk selama perkembangan seseorang dalam interaksinya dengan suatu objek ${ }^{35}$.

Travers, Gagne dan Cronbach dalam Sutarto menyebutkan ada tiga komponen dalam sikap, yakni (1) kognitif, komponen ini bertaut pada aspek pengetahuan, pikiran dan keyakinan yang didapatkan dari beragam informasi mengenai suatu entitas atau fenomena, (2) afektif, bertaut pada emosi seseorang yang biasanya menyangkut pada perasaan yang menggambarkan kesukaan atau kesenangan terhadap suatu fenomena, dan yang terakhir (3) konatif, hal ini menyangkut pada predisposisi untuk melakukan tindakan pada sesuatu,

\footnotetext{
${ }^{33}$ Zakiah Daradjat, Ilmu Jiwa Agama (Jakarta: Bulan Bintang, 1993), 91.

${ }^{34}$ Ibid., 58.

35 W.A. Gerungan, Psikologi Sosial (Bandung: PT. Refika Aditama, 2010), 163.
} 
singkatnya, komponen konatif memberikan kecenderungan untuk melakukan sesuatu. Dalam bahasa lain berarti, pengintegrasian antara kekuatan kepercayaan pada syariat agama, pengalaman rasa yang tentram dan menyukai syariat beragama, dan tindakan yang selaras dengan ajaran agama merupakan sikap dari keberagamaan remaja ${ }^{36}$.

\section{Pendidikan berbasis Sufistik}

Pendidikan Islam mengenal konsep fitrah dan akal pikiran sebagai objek dan subjek dalam pembahasannya, terlebih seluruh manusia ketika lahir ke dunia membawa masing-masing fitrahnya. Sedangkan akal pikiran memiliki tugas sebagai controller dari tercemar dan terjaganya fitrah manusia. Oleh karenanya, manusia harus memastikan pikirannya agar senantiasa berfungsi memikirkan yang baik sesuai dengan fitrahnya, pun dengan pikiran yang ideal mampu mengembangkan jiwa kemanusiaan pada diri manusia. Maka pengembangan akal pikiran dan pembentukan jiwa kemanusiaan menjadi urgensi untuk di dalami, agar manusia tak lekas kehilangan akal pikiran dan jiwa kemanusiaannya tatkala dibuai oleh nafsu duniawi. Pembahasan mendalam mengenai hal tersebut termasuk pada ruang lingkup kajian pendidikan sufistik ${ }^{37}$.

Pendidikan berbasis tasawuf apabila di lihat pada aspek sosial merupakan visi mengenai tatanan ideal masyarakat yang berlandaskan ajaran Islam $^{38}$. Eksistensi pendidikan sufistik pada mulanya bukanlah merupakan reaksi dari apatisnya warga muslim terhadap realita sosial, justru merupakan bentuk dari revolusi adab-spiritual dalam masyarakat yang menggambarkan landasan etika bagi perumusan sosial, melalui rangkaian cara pendidikan sufistik yang mengarahkan manusia pada keharmonian serta keseimbangan yang absolut ${ }^{39}$. Habib Luthfi menandaskan bahwa pendidikan sufistik yang memiliki prioritas pada kejernihan hati dan doktrin kemanusiaan pada

36 Sururin, Ilmu Jiwa Agama (Jakarta: PT. Raja Grafindo Persada, 2004), 7; Sutarto, "Pengembangan Sikap Keberagamaan Peserta Didik," 30.

37 Muis Sad Iman, "Impelementasi pendidikan sufisme dalam pendidikan islam," Muaddib: Studi Kependidikan Dan Keislaman 5, no. 2 (2016): 212.

38 Achmad Beadie Busyroel Basyar, "Pemikiran Syekh Ibnu Athaillah asSakandari tentang Pendidikan Sufistik dan Relevansinya dengan Pendidikan Karakter di Indonesia: Telaah Kitab al-Hikam al-'Atha>iyah", Magister, Tesis, UIN Maulana Malik Ibrahim, 2016, 6.

${ }^{39}$ Said Aqil Siradj, Tasawuf sebagai Kritik Sosial, 53. 
gilirannya akan menjadi solusi dari berbagai permasalahan masyarakat muslim di dunia ${ }^{40}$.

Pendidikan sufistik memiliki corak dalam pembentukan kepribadian dan nurani manusia, yang mana hal tersebut memberikan penekanan lebih khusus dari pada aspek spiritual. Menurut Basyar meski pendidikan sufistik dan spiritual memiliki kesamaan hal dalam menggerakkan potensi manusia ke arah lebih baik dan bermoral, pada keduanya terdapat perbedaan yang signifikan ${ }^{41}$. Pendidikan spiritual tidak selalu berkaitan dengan sesuatu yang bersifat ilâhiyah, dan berfungsi sebagai pelarian psikologis yang memuaskan obsesi dan ambisi terhadap kebutuhan rohaniah dan pencarian ketenangan tertentu. Sedangkan pendidikan sufistik menitikberatkan pada nubuat kegamaan yang sejati, mengasah hati untuk melampaui kesombongan serta sifat kehewanan. Juga sebagai tempat dalam memandang sudut pandang lain untuk memaknai dunia dan alam lain, yang berpotensi ada dan meliputi segala kenyataan.

Di sisi lain, Abu Bakar Atjeh memaparkan bahwa pendidikan spiritual merupakan proses pendidikan dan latihan yang berupaya mencari hubungan dengan Allah, sehingga dapat liqa' dan 'mempersatukan diri' dengan Tuhannya ${ }^{42}$. Menurut Suriadi pendidikan sufistik memberikan pandangan bahwa kesempurnaan dalam kehidupan melalui hadirnya stimulus pada jiwa yang bertaut dan dekat dengan Tuhan ${ }^{43}$. Habib Luthfi memaparkan bahwa pendidikan sufistik memiliki tujuan untuk membentuk diri dalam membersihkan hati dan jiwa hingga lekat dengan Allah serta Rasul-Nya ${ }^{44}$.

Para ulama Sufi memiliki tujuannya masing-masing dalam pendidikan sufistik, akan tetapi secara umum memiliki tujuan untuk mendekatkan diri pada Allah. Pun berbeda dengan metode untuk mencapai tujuan tersebut. Seperti Syeikh Abdul Qadir al-Jailani yang memaparkan konsep mengosongkan diri dari

40 Muhammad Isbiq, "Pemikiran Pendidikan Sufistik KH. Habib Luţfi bin 'Ali Yahya dan Respons Jama'ah Kanzus Şalawat di Pekalongan”, Magister, Tesis, IAIN Walisongo, 2011, 92.

${ }^{41}$ Basyar, "Pemikiran Syekh Ibnu Athaillah as-Sakandari tentang Pendidikan Sufistik dan Relevansinya dengan Pendidikan Karakter di Indonesia: Telaah Kitab alHikam al-Ata>iyah," 5.

42 Abu Bakar Atjeh, Pengantar Ilmu Tarekat (Uraian tentang Mistik) (Solo: Ramadhani, 2001), 42.

43 Suriadi Suriadi, "Pendidikan Sufistik Tarekat Qadiriyyah wa Naqsyabandiyyah (Kajian atas Pemikiran Ahmad Khatib Sambas)," Khazanah: Jurnal Studi Islam dan Humaniora 15, no. 2, 2018, (DOI: 10.18592/khazanah.v15i2.1899), 260.

${ }^{44}$ Isbiq, "Pemikiran Pendidikan Sufistik KH. Habib Luţfi bin 'Ali Yahya dan Respons Jama'ah Kanzus Şalawat di Pekalongan,” 90. 
sifat buruk (takhally), menghias diri dengan sifat yang baik (tahally), melalui anugerah dari Allah-lah ia ditampakkan kebenaran dan kebaikan padanya (tajally) ${ }^{45}$. Sementara itu Syeikh Ibnu Athaillah menawarkan konsep suluk dalam rangka wushul ila Allah ${ }^{46}$. Abu Yazid al-Bustami dengan metode ittihâd-nya ${ }^{47}, \mathrm{Al}$ Ghazali dengan konsep tazkiyyah an-nafs-nya ${ }^{48}$, Mansur al-Hallaj dengan metode hulul-nya ${ }^{49}$, Muhammad Arsyad al-Banjari melalui maqamat as-suluknya ${ }^{50}$, atau wahdat al-wujud-nya Ibnu 'Arabi51, dan masih banyak ulama sufi dengan konsep dan metodenya masing-masing.

Berdasarkan paparan di atas, maka dapat ditarik kesimpulan bahwa pendidikan sufistik merupakan proses pendidikan yang berupaya menanamkan nilai-nilai tasawuf melalui metode yang disarikan dari para ulama sufi yang menyasar pada aspek rekonstruksi hati dan jiwa, yang memiliki tujuan untuk mampu menerjemahkan tugas di dunia sebagai bekal untuk kehidupan setelahnya dan terutama sebagai upaya untuk taqarrub kepada Allah.

\section{Integrasi Sikap Keberagamaan Remaja dengan Pendidikan Sufistik a. Aspek Kognitif Remaja dalam Pendidikan Sufistik}

Puncak dari perkembangan kognitif berada pada masa remaja, aspek kognitif memiliki makna perolehan, penyusunan dan penggunaan pengetahuannya melalui pelibatan dari proses-proses psikologis ${ }^{52}$. Pada masa

45 Hafid Khairuddin, "Pendidikan Sufistik Syekh Abdul Qadir al-Jailani dan Relevansinya terhadap Pendidikan Islam; Telaah Kitab al-Fath ar-Rabbani wa al-Fayd ar-Rahmani", Magister, Tesis, UIN Sunan Kalijaga, 2014, 139.

46 Basyar, "Pemikiran Syekh Ibnu Athaillah as-Sakandari tentang Pendidikan Sufistik dan Relevansinya dengan Pendidikan Karakter di Indonesia: Telaah Kitab alHikam al-Ata>iyah," 131.

47 Dalmeri Dalmeri, "Menggugat Persatuan Roh Manusia dengan Tuhan: Dekonstruksi terhadap Paham Ittihad dalam Filsafat Abu Yazid al-Bustami," Madania: Jurnal Kajian Keislaman 20, no. 2, 2016, (DOI: 10.29300/madania.v20i2.163), 138.

${ }^{48} \mathrm{H}$ Taufik, "TAZKIYAH AL-NAFS: Konsep Pendidikan Sufistik dalam Upaya Membangun Akhlak," Jurnal TADRIS 6, no. 2 (2013): 211.

${ }^{49}$ Zulkifli Muhammad Nuh, "AL-HULUL; Sebuah Kontraversi Pencerahan dalam Pandangan Al-Hallaj," Madania: Jurnal Ilmu-Ilmu Keislaman 7, no. 2, 2017, (DOI: 10.24014/jiik.v7i2.4841), 218.

50 Bayani Dahlan, Pemikiran Sufistik Syekh Muhammad Arsyad al-Banjari (Banjarmasin: IAIN Antasari Press, 2014), 109.

${ }^{51}$ Kamaruddin Mustamain, "Ontologi Tasawuf Falsafi dalam Konsep Wahdatul Wujud Ibnu Arabi," Rausyan Fikr: Jurnal Studi Ilmu Ushuluddin Dan Filsafat 16, no. 2, 2020, (DOI: 10.24239/rsy.v16i2.630), 273.

52 Jean Piaget, Antara Tindakan dan Pikiran (Jakarta: Gramedia, 1988), 261. 
ini pun, pemrosesan informasi berkembang dengan cepat, lingkaran syaraf lobe frontal yang berperan sebagai aktifitas kognitif paling tinggi mengalami reorganisasi ke arah kemampuannya dalam merumuskan perencanaan yang strategis atau pengambilan keputusan ${ }^{53}$. Oleh karena itu dalam menyerap informasi, remaja lebih membutuhkan penjelasan yang bersifat fakta atau teori dari pada prinsip umum yang bersifat jawaban final, pun dalam menerima informasi perlu diiringi dengan bukti dari pada hanya menerima dari sumber yang otoritas ${ }^{54}$.

Dalam konsep Islam, Allah menempatkan manusia pada tahta tertinggi di muka bumi yang dibekali dengan pengalaman panca indera, sehingga mendapatkan pengetahuan pada akal pikiran dan termanifestasikan pada pekertinya. Dengannya manusia dapat memformulasikan tanda-tanda qauliyah dan kauniyah sebagai perwujudannya dalam mengemban tugas khalifah fi alardh. Akal merupakan potensi yang dimiliki manusia dan memiliki kedudukan yang sangat berharga, serta berfungsi untuk mengetahui hal yang bersifat materil, akan tetapi tak akan mampu mengetahui hakikat yang bersifat nonmateril 55 .

Sementara itu, pendidikan sufistik memiliki dominasi yang kuat pada aspek moral dan spiritual religius. Hal inipun yang membuat Akbarizan berpendapat bahwa pendidikan sufistik dapat menghambat aspek kognitif; daya kritis dan kreatif, penalaran ilmiah dan penelitian empirik. Ia menjelaskan di dalam tasawuf terlalu menjunjung tinggi ilmu kasyaf dari pada ilmu empirisilmiah, juga menitikberatkan pada perasaan serta pengalaman rohani dari pada berpikir kritis, dan memiliki paradigma teacher centered yang mungkin menutup kesempatan bagi muridnya untuk berpikir kritis, belajar sendiri dan mandiri ${ }^{56}$.

Sementara itu Al-Ghazali memandang akal sebagai jiwa yang bersifat rasional serta merupakan salah satu esensi dari manusia yakni qalb, ruh, nafs

53 Riryn Fatmawaty, “Memahami Psikologi Remaja," Jurnal Reforma 6, no. 2, 2017, (DOI: 10.30736/rfma.v6i2.33), 60.

${ }^{54}$ Khamim Zarkasih Saputro, "Memahami Ciri dan Tugas Perkembangan Masa Remaja," Aplikasia: Jurnal Aplikasi Ilmu-ilmu Agama 17, no. 1, 2018, (DOI: 10.14421/aplikasia.v17i1.1362), 30.

55 Marwan al-Kadiri, Keseimbangan antara Kebutuhan: Akal, Jasmani, dan Rohani (Jakarta: Cendekia Sentra Muslim, 2004), 102.

${ }^{56}$ Akbarizan Akbarizan dan Darmiyati Zuchdi, "Hambatan Sufisme terhadap Pendidikan Kognitif dan Sumbangan Sufisme terhadap Pendidikan Afektif," Jurnal Penelitian dan Evaluasi Pendidikan 4, no. 5, 2002 (DOI: 10.21831/pep.v4i5.2066), 34. 
dan 'aql (kognitif). Selanjutnya al-Ghazali memandang aspek kognitif ini memiliki daya untuk digunakan sebagai sarana kreativitas dan akhlak manusia, artinya perilaku baik manusia bersandar pada kemampuan akal dalam menguasai potensi jiwanya, fungsi ini ia sebut dengan al-'Amilat (praktis). Aspek kognitif yang selanjutnya disebut dengan al-'Alimat (teoritis) yang berfungsi sebagai penyempurna substansi yang bersifat immateril dan abstrak. Keduanya saling berhubungan satu sama lain, akal praktis menyalurkan tanggapan akal teoritis terhadap potensi penggerak yang memantiknya menjadi aktual ${ }^{57}$.

Akal teoritis berfungsi sebagai daya untuk mengetahui, maka kehendak manusia dalam berkeingintahuannya merupakan konsekuensi dari kinerja akal teoritis yang menggenapkan esensi yang bersifat immateril dan abstrak. Potensi kognitif remaja harus tetap diasah karena memang merupakan proses alamiah dalam perkembangan kognitifnya, dan pendidikan sufistik tidak hadir untuk membatasi hal tersebut. Baharuddin menyebutkan bahwa akal manusia menampung dua jenis akal, proses berpikir dengan menggunakan daya kognitif yang memiliki objek bahasan pada hal yang bersifat sensorik-empirik. Di sisi lain, akal pun mampu menerima pengetahuan yang bersifat abstrak-metafisika yang digabungkan dengan akal rohani dan qalb, hal ini merupakan inti dari kemampuan manusia pada ranah pengetahuan, kecerdasan, penalaran dan sebagainya ${ }^{58}$.

Selain alam nyata, Islam menetapkan adanya alam lain yang harus diyakini umat muslim sebagai limitasi dari keislamannya, yakni alam metafisik. Sementara akal dengan segala keunggulannya memiliki keterbatasan dalam menjangkau hal-hal yang bersifat ghaib, ia tidak menetap pada ruang dan waktu, maka kebenarannya pun tak dapat didiskusikan pada wilayah rasio-logika saja 59. Menurut Daud pengklasifikasian, penempatan dan penetapan akal ini bukan untuk mereduksi peran akal manusia, justru supaya memiliki benang merah yang umum dan paripurna, dan juga tidak bertabrakan dengan akal maupun logika ${ }^{60}$.

57 Muhammad Yasir Nasution, Manusia menurut al-Ghazali (Jakarta: Rajawali Pers, 1988), 97.

58 Baharuddin, Paradigma Psikologi Islam: Studi tentang Elemen Psikologi dari al-Qur'an (Yogyakarta: Pustaka Pelajar, 2004), 167.

${ }^{59}$ Rian Ardiansyah, "Konsep Akal dalam Tafsir al-Misbah”, Sarjana, Skripsi, UIN Raden Intan, 2018, 23-25.

60 Daud Rasyid, Islam dalam berbagai dimensi (Jakarta: Gema Insani Press, 1998), 93-94. 
Begitupun pada sudut pandang psikologi-sufistik, akal bukan hanya berkuasa pada aspek kognitif saja, namun bertaut pada aspek afektif, etika, dan psiko-transpersonal yang terus dikembangkan hingga batas yang maksimal, agar berperan sebagai instrumen peningkatan perilaku yang bermoral dan berpekerti yang luhur. Berbeda dengan psikologi modern yang berbasis positivistik, yang menentukan akal ditinjau hanya dari sudut kinerja inderawi dan hambar dengan aspek rasa, moralitas dan hal yang bersifat spiritualistik ${ }^{61}$. Oleh karenanya potensi kognitif remaja disini harus mampu mengerakkan informasi yang di dapatkan remaja pada penerimaan informasi, memahami dan membenarkan penyelidikan kritisnya untuk sampai pada ranah hakikat.

Transmisi ilmu dalam pendidikan sufistik memang dibedakan berdasarkan potensi dan kompetensi muridnya. Pada tahap remaja, hendaknya pernyataan yang disampaikan oleh Habib Lutfi bin Yahya patut menjadi perhatian bagi usia remaja, mengingat dahaga remaja terhadap daya kritisnya yang begitu tinggi itu diawali dengan pendidikan syariat dengan tujuan tasawuf62. Integrasi antara pengetahuan kognitif dengan qalb ini menurut Imam Malik dapat membebaskan seseorang dari perilaku yang menyimpang dari ajaran agama, selain itu dapat meyakini bahwa ilmu pengetahuan yang sejati adalah nur yang diberikan Allah ke dalam qalb63. Pemahaman kognitif yang mendalam mengenai agama Allah yang diberikan ke dalam sanubari, sehingga membuatnya menaati, mengikuti, memahami dan memiliki pengetahuan mengenai agama Allah.

Hal ini dilakukan agar susunan dari pengetahuan syariat sebelumnya disambungkan sehingga tersusun hipotesisnya mengenai hal-hal yang abstrak, mengingat kognitif remaja memang sangat mungkin untuk terjadinya transformasi dari penalaran sederhana kepada yang lebih kompleks. Pembekalan pendidikan syariat dengan tujuan tasawuf ini tentu harus di bawah bimbingan seorang guru, sebab dalam tasawuf guru berperan bukan hanya sebagai pembimbing rohani muridnya saja, tetapi sekaligus sebagai pengawas kehidupan rohani muridnya agar senantiasa berada pada jalurnya.

61 Abdullah Hadziq, "Psikologi Sufistik: Upaya Menawarkan Solusi Pengembangan Pendidikan Multicultural," Pidato Pengukuhan Guru Besar, Semarang: IAIN Walisongo, 2007), 19-20.

62 Isbiq, "Pemikiran Pendidikan Sufistik KH. Habib Luţfi bin 'Ali Yahya dan Respons Jama'ah Kanzus Şalawat di Pekalongan," 90.

${ }^{63}$ Asep Usman Ismail, "Integrasi Syariah dengan Tasawuf," AHKAM: Jurnal Ilmu Syariah 12, no. 1, 2012, (DOI: 10.15408/ajis.v12i1.987), 135. 
Guru dalam tasawuf bukan hanya dituntut dalam menyelesaikan target suatu materi, tetapi tanggung jawab dan otoritas yang dimilikinya, sehingga ilmu dapat mengalir dengan jernih dan dapat diserap sempurna oleh muridmuridnya. Begitu pentingnya hal tersebut bahkan seorang guru dalam tarekat sufi harus mencapai taraf maqam rijal al-kamal yakni kesempurnaan dalam melaksanakan syariah secara tarekat sehingga mencapai hakikat dan ma'rifat ${ }^{64}$. Hal ini dilakukan agar memastikan bahwa ajaran Islam yang diterima remaja bukan hanya pada taraf diketahui saja, namun sungguh-sungguh difahami dan dijiwai hingga membangkitkan keinginannya untuk menapaki hidup yang selaras dengan syariat ${ }^{65}$.

Dari berbagai pernyataan yang telah diungkap di atas, pengembangan aspek kognitif melalui pendidikan sufistik bagi remaja selain menghadirkan upaya penyampaian pengetahuan syariat agama seperti konsep syahadat, shalat, zakat, puasa, haji dan sebagainya, hal selanjutnya menyinkronkan dengan ungkapan yang berorientasi kepada penekanan kesabaran dalam menjalankannya, ikhlas dalam pengerjaannya, yang kemudian pertanyaan di dalam benaknya bukan seberapa banyak ia melaksanakannya, namun seberapa tinggi kualitasnya, bukan lagi pertanyaan mengapa manusia diwajibkan beribadah, namun mengapa manusia rela meninggalkan ibadah. Sehingga aspek pengetahuan dalam syariat ini bertransformasi menjadi keyakinan dan diterjemahkan dengan kehidupan yang bertasawuf yang dilandasi oleh syariat.

\section{b. Pengembangan Aspek Afektif Remaja dalam Pendidikan Sufistik}

Seperti halnya aspek kognitif remaja yang ditandai dengan beberapa perubahannya, demikian pula halnya dengan aspek afektif. Aspek ini berkaitan dengan kemampuan remaja dalam memberikan respon, emosi dan perasaan terhadap suatu objek yang berdasarkan pada penilaiannya secara kognitif 66 . Akan tetapi pada masa ini, peningkatan emosi terjadi begitu cepat sebagai hasil dari perubahan hormonnya. Di sisi lain, remaja menyadari bahwa kondisinya berbeda dari masa sebelumnya, ia mulai diberikan tuntutan dan tekanan dari lingkungannya seperti mengharapkan ia tidak berlaku seperti kanak-kanak, berdikari, dan memiliki tanggung jawab67.

\footnotetext{
${ }^{64}$ M. Syafiq Humaisi, "Transmisi Ilmu dalam Pendidikan Sufistik," Cendekia: Jurnal Kependidikan Dan Kemasyarakatan 10, no. 2, 2012, (DOI: 10.21154/cendekia.v10i2.413), 238.

65 Fatmawaty, "Memahami Psikologi Remaja," 64.

${ }^{66}$ Azwar, Sikap Manusia Teori dan Pengukurannya, Edisi ke-2.

${ }^{67}$ Saputro, "Memahami Ciri dan Tugas Perkembangan Masa Remaja," 28.
} 
Reaksi pergeseran kondisi sosial pada seorang remaja ini menimbulkan beberapa perubahan dalam dirinya, seperti meningginya emosi yang dirasakan. Hal ini merupakan hal yang wajar bagi usia remaja, sebab pada masa remaja rentan timbul gejolak dalam emosi dan tekanan jiwa. Yang harus menjadi perhatian adalah ketika tekanan tersebut mengakibatkan remaja memiliki sikap menyimpang dari aturan dan norma sosial, mulai menganggap wajar dan menyukai hal yang membelot dari ajaran agamanya. Oleh karenanya, peran agama menjadi concern dalam mencurahkan apa yang dirasakan hingga menyatu dalam sikapnya dalam kehidupan sehari-hari.

Pendidikan sufistik dalam ajarannya menyasar pada ranah qalb, yang mana hal tersebut bukan hanya mampu menetapkan sikap, namun mampu mengarahkan pada perilaku seseorang. Dalam pandangan sufistik, kecerdasan bukan hanya dilihat dari kecerdasan otaknya saja, akan tetapi adalah kecerdasan yang hakiki, yakni qalb yang mampu menentukan baik atau buruknya suatu objek. Bukan hanya menjadikan seseorang menjadi pandai dalam menilai, namun pintar dalam merasakan, bukan hanya memiliki pengetahuan bahwa korupsi itu adalah tindakan yang jahat, namun lebih pada rasa yang teraktualisasikan dalam jiwa-nya untuk tidak melakukan korupsi68.

Guru dalam pendidikan sufistik mengetahui bahwa nilai dasar keperluan manusia merupakan hal yang urgensi untuk dipenuhi, nilai dasar yang juga sebagai nilai luhur itu adalah iman dan takwa. Hal ini merupakan potensi dalam diri remaja untuk membantu dalam penemuan identitas remaja, membuat remaja cerdas dalam aspek kognitif serta emosinya, hingga mempertajam pemahaman agamanya, kemudian mendorong serta memacu serta membimbing akhlak serta kepribadian berdasarkan nilai ketauhidan melalui pendekatan yang menyenangkan ${ }^{69}$.

Interaksi antara guru dan murid dalam pendidikan sufistik melalui pendekatan psikologis humanis yang akrab, ramah dan menyenangkan merupakan suatu keniscayaan. Seperti proses interaksi dalam tarekat sufi yang memiliki keyakinan dalam setiap transmisi ilmu merupakan pijakan ibadah. Guru dalam pendidikan sufistik bak seperti dokter yang sedang mengobati pasiennya, ia mengetahui dan mampu mendiagnosis penyakit yang ada pada

${ }^{68}$ Riski Prasetya, "Konsep Pendidikan Multikultural bagi Pengembangan Afeksi Anak: Studi Pemikiran Prof. Dr. H. Abdullah Hadziq, MA tentang Pendidikan Multikultural berbasis Afektif Sufistik", Sarjana, Skripsi, UIN Walisongo, 2018, 61.

69 Oktaviani Umayah, "Implementasi Pendidikan Afektif dalam Pembentukan Akhlak Mulia," Elementary: Jurnal Ilmiah Pendidikan Dasar 3, no. 2, 2017, (DOI: 10.32332/elementary.v3i2.996), 171. 
muridnya, termasuk dalam hal usia muridnya yang bervariatif dengan perlakuan yang juga berbeda. Guru dalam pendidikan sufistik memahami gejolak yang ada dalam diri remaja, dan mereka mampu memperhatikan kondisi serta jalan keluarnya ${ }^{70}$.

Selain itu pendidikan sufistik dalam lingkungannya memberikan tempat yang tepat bagi proses perkembangan afektif remaja. Sufi memberikan doktrin untuk mengindahkan kebersamaan dan solidaritas diantara sesama di setiap harinya, sehingga memungkinkan terciptanya hubungan dengan suasana yang akrab dan menolak segala perbedaan, baik itu materil, pekerjaan maupun status sosial. Bagi remaja hal tersebut dapat pula menjadi ranah dalam proses perkembangannya, di dalamnya terbangun kondisi saling bertukar pengalaman yang positif, relasi, memupuk semangatnya dalam mencapai prestasi, memperluas wawasan dan pergaulan ${ }^{71}$.

Penjelasan di atas menggambarkan bahwa dalam mematangkan sikap keberagamaan remaja membutuhkan suasana yang mampu menetapkan fluktuasinya perkembangan emosi jiwa remaja. Pendekatan dan metode guru dalam memantik kecerdasan emosional remaja melalui metode 'ibrah, hikmah dalam setiap fase kehidupan akan menggubah suasana hati dan jiwa remaja ke arah yang positif. Selain itu orangtua dan kerabat yang terlingkup pada satu lingkungan yang bercorak psikologis-humanis akan memberikan kemudahan dalam memantapkan aspek afektif remaja.

\section{c. Pengembangan Aspek Konatif Remaja dalam Pendidikan Sufistik}

Perkembangan agama usia remaja memang sangat rentan terpengaruhi oleh dorongan nyata dari luar. Hal ini mulai menjadi permasalahan ketika remaja terpapar pengaruh negatif dari lingkungannya, mengingat jiwa keagamaan pada jenjang ini masih belum kuat dalam menyaring informasi yang ada di lingkungan sehingga dengan ketidak stabilan emosi yang ada mendorong untuk mengerjakan pengingkaran norma agama dan sosial.

Gejala yang timbul pun beragam, diantaranya adalah mengidolakan sesuatu secara berlebihan. Dewasa ini kerap terjadi pada fase usia remaja, sebab secara sadar ia memahami bahwa dirinya kesepian, yang tentu belum pernah

70 Humaisi, "Transmisi Ilmu dalam Pendidikan Sufistik," 241; Abdul Wasik, "Pengontrolan Diri Kaum Remaja dengan Pengamalan Thariqat Qodiriyah Naqsyabandiyah di Kabupaten Bandung," Hanifiya: Jurnal Studi Agama-Agama 3, no. 2, 2020, (DOI: 10.15575/hanifiya.v3i2.10010), 95.

71 Wasik, "Pengontrolan Diri Kaum Remaja dengan Pengamalan Thariqat Qodiriyah Naqsyabandiyah di Kabupaten Bandung," 96. 
dialami sebelumnya. Baginya, kesepian adalah penderitaan. Sebab tak ada yang mampu mengerti dan memahaminya, sehingga ia berusaha mencari teman yang satu frekuensi dengannya. Yang kemudian tumbuh keinginan untuk mencari pegangan hidup, mengejar suatu hal yang mereka rasa layak untuk dijunjung tinggi, bernilai dan pantas disanjungi. Disisi lain ia tidak mau menggunakan sikap/pedoman hidup ketika masa kanak-kanaknya ${ }^{72}$.

Remaja pada fase ini yang ia butuhkan adalah pengharapannya pada sesuatu yang dapat mengerti, memahami dan mampu untuk menenangkannya, dalam konsep tasawuf dikenal dengan konsep khauf wa al-raja', Imam Qusyairi memaparkan bahwa pengharapan ialah keterikatan hati pada suatu hal yang diharapkan terjadi pada masa kemudian, seperti halnya khauf ${ }^{73}$. Yang mana keduanya harus menyatu dalam diri seorang mukmin, agar tidak menjadi fatamorgana dan tidak berarti ${ }^{74}$.

Oleh karena itu, harapan adalah sebuah motivasi yang menggerakkan pada perbuatan. Motivasi remaja hendaknya diasah untuk memiliki keinginan dalam mencapai maqam tertinggi dan harapannya bertemu dengan Allah menjadi satu cita-cita tersendiri bagi siswa, melalui pembiasaan berdzikir mengingat Allah, sebab tak ada yang dapat menenangkan hati kecuali dengan berdzikir. Sehingga pada akhirnya remaja memiliki suatu dorongan dalam dirinya untuk melakukan tindakan yang sesuai dengan keyakinan (kognitif), keinginan dan perasaannya (afektif) dan dorongan tersebut yang dinamakan dengan aspek konatif.

Pendidikan sufistik mengajarkan mengenai keindahan, sebagaimana tabiat manusia yang menghendaki keindahan dan keelokan, maka keinginan dalam mencintai Allah merupakan hal yang juga manusiawi, terlebih Allah merupakan sumber dari keindahan, sehingga keinginan manusia hanyalah dalam rangka mendapatkan cinta dari dzat Allah yang maha abadi. Pemahaman inilah yang berimbas pada keteguhan hati bahwa proses terciptanya alam semesta memiliki motif dasar dari cinta Allah. Alam semesta merupakan pengejawantahan cinta Allah yang dikontemplasikan pada wujud empirik

${ }^{72}$ Fakhrul Rijal, "Perkembangan Jiwa Agama pada Masa Remaja (Al-Murahiqah)," PIONIR: Jurnal Pendidikan 5, no. 2, 2016, (DOI: 10.22373/pjp.v5i2.3354), 6.

${ }^{73}$ Mohd Amir Bin Japri, "Konsep Khauf dan Raja' Imam al-Ghazali dalam Terapi Gangguan Kecemasan”, Sarjana, Skripsi, UIN Sumatera Utara, 2017, 57.

${ }^{74}$ Muzakkir, Tasawuf Jalan Mudah Menuju Tuhan (Medan: Perdana Publising, 2012), 106-7. 
selaku mazhâhir dari asmâ' Allah, termasuk pada penciptaan dirinya, masalah yang ada pada dirinya merupakan bentuk dari kasih sayang Allah ${ }^{75}$.

Aktifitas tafakkur di atas merupakan pertalian antara potensi kognitif, afektif, dan spiritual yang menimbulkan pengalaman keagamaan. Proses memikirkan penciptaan alam merupakan kegiatan yang berpusat pada akal, dengan diliputi oleh semangat mengingat Allah yang bertaut pada qalb. Syeikh Abul Hasan asy-Syadzili memaparkan konsep dasar bagi seseorang untuk berjalan menuju Allah, salah satunya adalah tafakkur. Ia menyebutkan bahwa apabila seseorang telah mengamalkan dengan baik salah satu dari empat konsep yang ia sebutkan (dzikir, tafakkur, fakir dan cinta) merupakan hamba Allah yang shaleh. Asy-Syadzili memandang pentingnya hal tersebut agar kemudian hati seseorang tetap 'tersambung' dengan Allah ${ }^{76}$.

Tafakkur secara sederhana dapat dilakukan dengan merenungkan seluruh ciptaan Allah sehingga menimbulkan kekaguman dan rasa cinta pada sang pencipta, proses perenungan ini dapat dilakukan baik terhadap apa yang ada dalam dirinya maupun apa yang ada disekitarnya. Mengingat daya tualang remaja yang tinggi, hal ini dapat dilakukan dengan rihlah terhadap fenomena alam di sekelilingnya, agar mereka mengetahui dan menyadari identitas diri, seperti apa tujuan hidupnya, menemukan setiap hikmah dalam berbagai permasalahan baru dalam hidupnya, dan yang terpenting adalah agar remaja mampu memperkuat keimanannya kepada Allah, sehingga remaja mampu memandang dunia dengan penuh pelajaran berharga dari setiap peristiwanya. Hal ini juga yang akan menumbuhkan kemampuannya dalam memotivasi diri sendiri yang mengerakkannya pada perbuatan.

Agar memudahkan dalam memahami integrasi antara komponen sikap dengan pendidikan sufistik, dapat digambarkan pada bagan di bawah ini.

75 Iman, "Impelementasi pendidikan sufisme dalam pendidikan islam," 215.

76 Muhammad Rizal Ansori, Duski Ibrahim, dan Munir Munir, "Konsep Pendidikan Sufistik Menurut Syeh Abu Hasan Asy-Sadzily (Tela'ah Kitab Risalatul Amin Fi Wusuli Li Robbil Alamin)," Muaddib: Islamic Education Journal 2, no. 1 (2019): 62. 


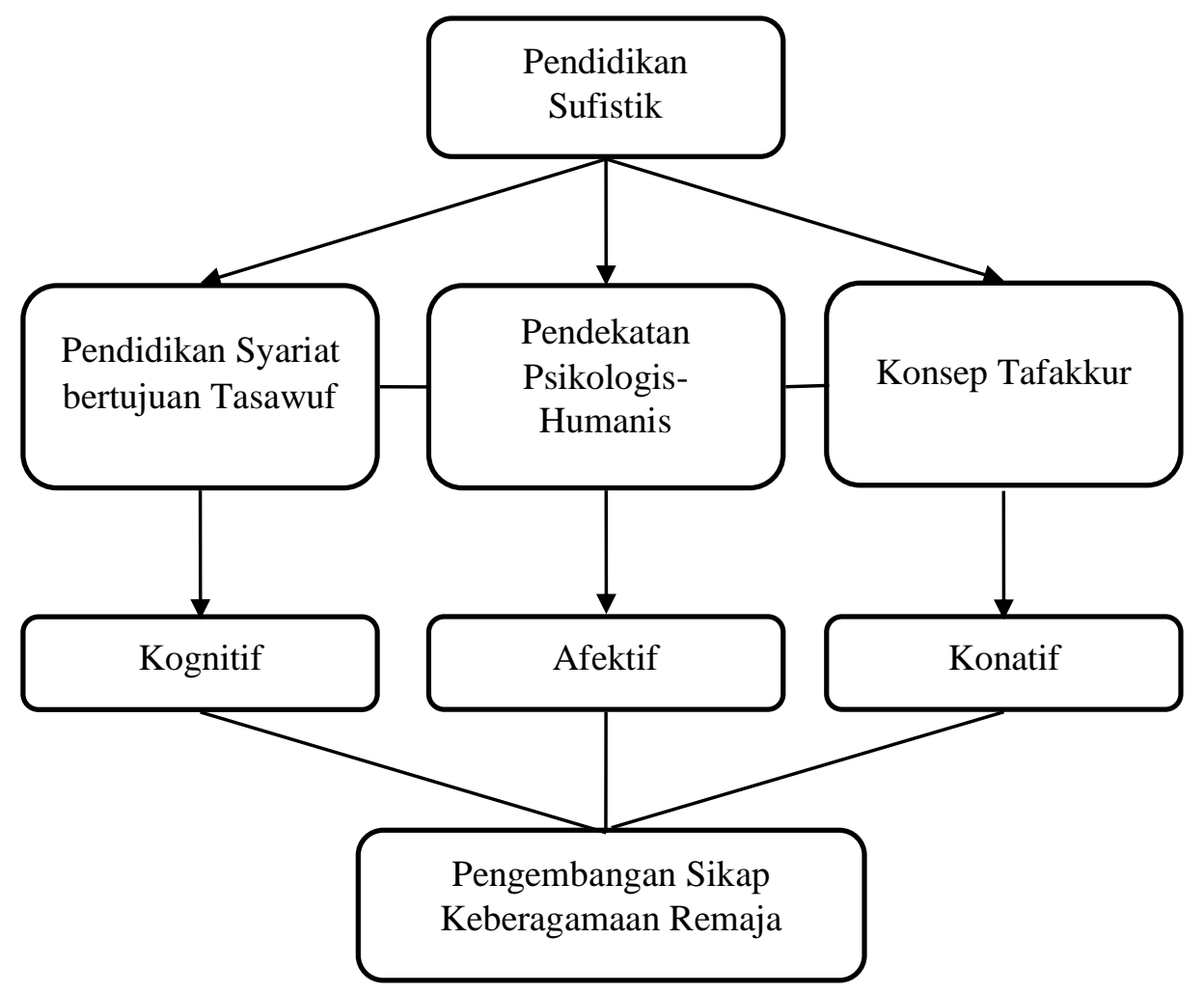

Gambar 1. Integrasi Komponen Sikap dengan Pendidikan Sufistik

Dalam upaya memelihara sikap keberagamaan remaja, membutuhkan perlakuan disiplin dalam beragama. Kedisiplinan tersebut dapat lahir dari (1) keteladanan orang tua atau guru yang taat dalam beragama, (2) penanaman rasa keimanan yang berimbas pada ketakutannya pada Allah apabila mengabaikan ajaran agamanya, serta (3) terciptanya kondisi sosial yang juga taat dalam hal agama ${ }^{77}$. Oleh karena itu, pembentukan budaya keagamaan yang berintegrasi antara orang tua dan lingkungan (termasuk sekolah) diharapkan dapat membentuk sikap keberagamaan remaja. Termasuk pada peningkatan kualitas pendidikan akhlak yang diterapkan agar sikap keagamaan remaja tertancap dengan istiqamah.

\section{Kesimpulan}

77 Triana Rosalina Noor, "Remaja dan Pemahaman Agama," Vicratina: Jurnal Pendidikan Islam 3, no. 2 (2019): 57. 
Sikap keberagamaan remaja yang ditandai dengan beberapa perkembangan dan perubahan dalam hal fisik maupun psikis melahirkan efek yang fundamental pada perkembangan sikap keberagamaannya pada fase selanjutnya, sikap ini timbul atas kesadaran remaja dalam menentukan perbuatan. Untuk menentukan kesadaran tersebut terbagi menjadi beberapa aspek, seperti kognitif, afektif dan konatifnya. Pendidikan sufistik hadir dalam mengembangkan ketiga komponen tersebut, dengan mengembangkan aspek kognitif remaja dengan mengajarkan mereka ilmu syariat namun dengan tujuan tasawuf, membimbing aspek afektif dengan pendekatan psikologis-humanis, dan mengembangkan daya konatifnya dengan cara tafakkur. Hal ini harus terus diasah agar remaja senantiasa berada pada jalan kebajikan dengan memberikan disiplin pada lingkungan mereka, seperti teladan dari guru dan orang tua, penanaman rasa iman dalam diri remaja, dan lingkungan yang beragama. Namun demikian, penelitian ini memiliki keterbatasan yakni belum diterapkannya pada tataran praktis, sehingga untuk menyempurnakan dan memperluas penelitian ini hendaknya untuk dikembangkan melalui pengujian yang bersifat eksperimental.

\section{Bibliografi}

Abu Bakar Atjeh. Pengantar Ilmu Tarekat (Uraian tentang Mistik). Solo: Ramadhani, 2001.

Akbarizan, Akbarizan, dan Darmiyati Zuchdi. "Hambatan Sufisme terhadap Pendidikan Kognitif dan Sumbangan Sufisme terhadap Pendidikan Afektif." Jurnal Penelitian dan Evaluasi Pendidikan 4, no. 5 (2002): 31-37. doi:https://doi.org/10.21831/pep.v4i5.2066.

Al-Taftazani, Abu al-Wafa al-Ghanimi. Sufi dari Zaman ke Zaman. Bandung: Pustidaka, 1985.

Ansori, Muhammad Rizal, Duski Ibrahim, dan Munir Munir. "Konsep Pendidikan Sufistik Menurut Syeh Abu Hasan Asy-Sadzily (Tela'ah Kitab Risalatul Amin Fi Wusuli Li Robbil Alamin).” Muaddib: Islamic Education Journal 2, no. 1 (2019): 60-69.

Anwar, Rosihon, dan Mukhtar Solikhin. Ilmu Tasawuf. Bandung: Pustaka Setia, 2004.

Aziz, Safrudin. "Pendidikan Spiritual berbasis Sufistik bagi Anak Usia Dini dalam Keluarga.” Dialogia: Jurnal Studi Islam Dan Sosial 15, no. 1 (2017): 131-49. doi:10.21154/dialogia.v15i1.1188. 
126 | FOKUS: Jurnal Kajian Keislaman dan Kemasyarakatan, vol. 6, no. 2, 2021

Azwar, Saifuddin. Sikap Manusia Teori dan Pengukurannya, Edisi ke-2. Yogyakarta: Pustaka Pelajar, 2013.

Bafadal, Fadhal AR. Pemuda dan Pergumulan Nilai pada Era Global. Jakarta: Badan Litbang Agama dan Diklat Keagamaan, 2003.

Baharuddin. Paradigma Psikologi Islam: Studi tentang Elemen Psikologi dari alQur'an. Yogyakarta: Pustaka Pelajar, 2004.

Basyar, Achmad Beadie Busyroel. "Pemikiran Syekh Ibnu Athaillah as-Sakandari tentang Pendidikan Sufistik dan Relevansinya dengan Pendidikan Karakter di Indonesia: Telaah Kitab al-Hikam al-Ata>iyah." Tesis-Universitas Islam Negeri Maulana Malik Ibrahim, 2016.

Dahlan, Bayani. Pemikiran Sufistik Syekh Muhammad Arsyad al-Banjari. Banjarmasin: IAIN Antasari Press, 2014.

Dalmeri, Dalmeri. "Menggugat Persatuan Roh Manusia dengan Tuhan: Dekonstruksi terhadap Paham Ittihad dalam Filsafat Abu Yazid alBustami." Madania: Jurnal Kajian Keislaman 20, no. 2 (2016): 137-50. doi:dx.doi.org/10.29300/madania.v20i2.163.

Daradjat, Zakiah. Ilmu Jiwa Agama. Jakarta: Bulan Bintang, 1993.

Deti Mega Purnamasari. "Kementerian PPPA: Naiknya Kasus Narkoba Anak Jadi Alarm bagi Orangtua." kompas.com. Diakses 13 Februari 2021.https://nasional.kompas.com/read/2020/06/26/17590051/keme nterian-pppa-naiknya-kasus-narkoba-anak-jadi-alarm-bagiorangtua?page=all.

Fatmawaty, Riryn. "Memahami Psikologi Remaja." Jurnal Reforma 6, no. 2 (2017). doi:10.30736/rfma.v6i2.33.

Fitriana, Fitriana, dan Feriska Listrianti. "Pendidikan Akhlak Perspektif AlGhazali dalam Mengatasi Rational Hedonism di MTS Negeri 1 Probolinggo." Risâlah, Jurnal Pendidikan dan Studi Islam 6, no. 1, March (2020): 100-116.

Gani, A. "Pendekatan Sufistik Dalam Pendidikan Islam Berwawasan Perdamaian." AKADEMIKA: Jurnal Pemikiran Islam 23, no. 2 (2018): 387412. doi:10.32332/akademika.v23i2.1239.

Gerungan, W.A. Psikologi Sosial. Bandung: PT. Refika Aditama, 2010.

Hadziq, Abdullah. "Psikologi Sufistik: Upaya Menawarkan Solusi Pengembangan Pendidikan Multicultural." Pidato Pengukuhan Guru Besar. Semarang: IAIN 
Walisongo. Semarang, 2007.

Hafid Khairuddin. "Pendidikan Sufistik Syekh Abdul Qadir al-Jailani dan Relevansinya terhadap Pendidikan Islam; Telaah Kitab al-Fath ar-Rabbani wa al-Fayd ar-Rahmani." Tesis-UIN Sunan Kalijaga, 2014.

Humaisi, M. Syafiq. “Transmisi Ilmu dalam Pendidikan Sufistik.” Cendekia: Jurnal Kependidikan Dan Kemasyarakatan 10, no. 2 (2012): 233-34. doi:10.21154/cendekia.v10i2.413.

Iman, Muis Sad. "Impelementasi pendidikan sufisme dalam pendidikan islam." Muaddib: Studi Kependidikan Dan Keislaman 5, no. 2 (2016): 208-25.

Isbiq, Muhammad. "Pemikiran Pendidikan Sufistik KH. Habib Luţfi bin 'Ali Yahya dan Respons Jama'ah Kanzus Şalawat di Pekalongan.” Tesis-IAIN Walisongo, 2011.

Islami, Anggi Anggraeni, dan Rifki Rosyad. "Pendidikan Anak Perspektif Sufistik Dalam Pandangan Ibnu Qayyim Al Jauziyah." Syifa al-Qulub 4, no. 2 (2020): 34-38. doi:doi.org/10.15575/saq.v4i2.7587.

Ismail, Asep Usman. "Integrasi Syariah dengan Tasawuf." AHKAM: Jurnal Ilmu Syariah 12, no. 1 (2012). doi:10.15408/ajis.v12i1.987.

Japri, Mohd Amir Bin. "Konsep Khauf dan Raja' Imam al-Ghazali dalam Terapi Gangguan Kecemasan." Skripsi-Universitas Islam Negeri Sumatera Utara, 2017.

Kahmad, Dadang. Sosiologi Agama. Bandung: Remaja Rosdakarya, 2000.

Langi, Gaby Gabriela. "Millenials dan HIV Aids." pph.atmajaya.ac.id. Diakses 13 Februari 2021. https://pph.atmajaya.ac.id/berita/artikel/millennialsdan-hiv-aids/.

Lastri, Sulastri, Eti Hayati, dan Aulia Nursyifa. "Dampak Kenakalan Remaja Untuk Meningkatkan Kesadaran Dari Bahaya Kenakalan Remaja Bagi Masa Depan." Jurnal Loyalitas Sosial: Journal of Community Service in Humanities and Social Sciences 2, no. 1 (2020): 15-24. doi:10.32493/jls.v2i1.y2020.p15-24.

Mareta, Mira. "Peran Pendidikan Agama dalam Pembentukan Perilaku Keberagamaan Siswa Madrasah Aliyah Pedesaan dan Perkotaan di Pulau Lombok." Disertasi-UIN Sunan Kalijaga, 2019.

Marwan al-Kadiri. Keseimbangan antara Kebutuhan: Akal, Jasmani, dan Rohani. 
128 | FOKUS: Jurnal Kajian Keislaman dan Kemasyarakatan, vol. 6, no. 2, 2021

Jakarta: Cendekia Sentra Muslim, 2004.

Mubarak, Ahmad Zakki. "Perkembangan Jiwa Agama." Ittihad Jurnal Kopertais Wilayah XI 12, no. 22 (2017): 91-106.

Mulkhan, Abdul Munir. Nalar Spiritual Pendidikan: Solusi Problem Filosofis Pendidikan Islam. Yogyakarta: Tiara Wacana Yogya, 2002.

Mustamain, Kamaruddin. "Ontologi Tasawuf Falsafi dalam Konsep Wahdatul Wujud Ibnu Arabi." Rausyan Fikr: Jurnal Studi Ilmu Ushuluddin Dan Filsafat 16, no. 2 (2020): 267-81. doi:10.24239/rsy.v16i2.630.

Muzakkir. TasawufJalan Mudah Menuju Tuhan. Medan: Perdana Publising, 2012.

Nasution, Muhammad Yasir. Manusia menurut al-Ghazali. Jakarta: Rajawali Pers, 1988.

Ngalim Purwanto. Psikologi Pendidikan. Bandung: Remaja Rosdakarya, 2004.

Noor, Triana Rosalina. "Remaja dan Pemahaman Agama." Vicratina: Jurnal Pendidikan Islam 3, no. 2 (2019): 54-70.

Nuh, Zulkifli Muhammad. "AL-HULUL; Sebuah Kontraversi Pencerahan dalam Pandangan Al-Hallaj." Madania: Jurnal Ilmu-Ilmu Keislaman 7, no. 2 (2017): 211-31. doi:10.24014/jiik.v7i2.4841.

Piaget, Jean. Antara Tindakan dan Pikiran. Jakarta: Gramedia, 1988.

Prasetya, Riski. “Konsep Pendidikan Multikultural bagi Pengembangan Afeksi Anak: Studi Pemikiran Prof. Dr. H. Abdullah Hadziq, MA tentang Pendidikan Multikultural berbasis Afektif Sufistik." Skripsi-UIN Walisongo Semarang, 2018.

Puslitdatin. "Penggunaan Narkotika di kalangan Remaja Meningkat." bnn.go.id. Diakses 13 Februari 2021. https://bnn.go.id/penggunaan-narkotikakalangan-remaja-meningkat/.

Qomarudin, A. "Pendekatan Sufistik dalam Pembelajaran Pendidikan Agama Islam." Piwulang: Jurnal Pendidikan Agama Islam 2, no. 1 (2019): 25-35. doi:10.32478/piwulang.v2i1.299.

Rakhmat, Jalaluddin. Psikologi Agama: Sebuah Pengantar. Bandung: Mizan Pustaka, 2013.

Ramayulis. Psikologi Agama. Jakarta: Kalam Mulia, 2019. 
Rasyid, Daud. Islam dalam berbagai dimensi. Jakarta: Gema Insani Press, 1998.

Rian Ardiansyah. "Konsep Akal dalam Tafsir al-Misbah.” Lampung: Skripsi-UIN Raden Intan, 2018.

Rijal, Fakhrul. "Perkembangan Jiwa Agama pada Masa Remaja (Al-Murahiqah).” PIONIR: Jurnal Pendidikan 5, no. 2 (2016). doi:10.22373/pjp.v5i2.3354.

Sahlan, Asmaun. Mewujudkan Budaya Religius di Sekolah: Upaya Mengembangkan PAI dari Teori ke Aksi. Malang: UIN Maliki-Press, 2010.

Said Aqil Siradj. Tasawuf sebagai Kritik Sosial. Bandung: Mizan Pustaka, 2006.

Saputra, Eddy. "Dampak Sosial Media Terhadap Sikap Keberagamaan Remaja Dan Solusinya Melalui Pendidikan Agama Islam.” Sosio e-Kons 8, no. 2 (2016). doi:10.30998/sosioekons.v8i2.922.

Saputro, Khamim Zarkasih. "Memahami Ciri dan Tugas Perkembangan Masa Remaja." Aplikasia: Jurnal Aplikasi Ilmu-ilmu Agama 17, no. 1 (2018): 2532. doi:10.14421/aplikasia.v17i1.1362.

Suriadi, Suriadi. "Pendidikan Sufistik Tarekat Qadiriyyah wa Naqsyabandiyyah (Kajian atas Pemikiran Ahmad Khatib Sambas)." Khazanah: Jurnal Studi Islam dan Humaniora 15, no. 2 (2018): 263-70. doi:10.18592/khazanah.v15i2.1899.

Sururin. Ilmu Jiwa Agama. Jakarta: PT. Raja Grafindo Persada, 2004.

Sutarto, Sutarto. "Pengembangan Sikap Keberagamaan Peserta Didik." Islamic Counseling: Jurnal Bimbingan dan Konseling Islam 2, no. 1 (2018): 21-42. doi:dx.doi.org/10.29240/jbk.v2i1.468.

Tafsir, Ahmad. Metodologi Pengajaran Agama Islam. Bandung: Remaja Rosdakarya, 2008.

Tafsir, Ahmad, Ahmad Supardi, Hasan Basri, Mahmud Mahmud, Opik Taupik Kurahman, Pupuh Fathurrahman, Tedi Priatna, Supriatna Supriatna, Uus Ruswandi, dan Yaya Suryana. Cakrawala Pemikiran Pendidikan Islam. Vol. 1. Bandung: Mimbar Pustaka: Media Tranformasi Pengetahuan, 2004.

Taufik, H. "TAZKIYAH AL-NAFS: Konsep Pendidikan Sufistik dalam Upaya Membangun Akhlak." Jurnal TADRIS 6, no. 2 (2013): 203-25.

Umayah, Oktaviani. "Implementasi Pendidikan Afektif dalam Pembentukan Akhlak Mulia." Elementary: Jurnal Ilmiah Pendidikan Dasar 3, no. 2 (2017): 
130 | FOKUS: Jurnal Kajian Keislaman dan Kemasyarakatan, vol. 6, no. 2, 2021

158-72. doi:10.32332/elementary.v3i2.996.

Wasik, Abdul. "Pengontrolan Diri Kaum Remaja dengan Pengamalan Thariqat Qodiriyah Naqsyabandiyah di Kabupaten Bandung." Hanifiya: Jurnal Studi Agama-Agama 3, no. 2 (2020): 87-98. doi:10.15575/hanifiya.v3i2.10010. 